University of Michigan Law School

University of Michigan Law School Scholarship Repository

1921

\title{
The Usefulness of Intervention as a Remedy in Attachment
}

Edson R. Sunderland

University of Michigan Law School

Available at: https://repository.law.umich.edu/articles/1102

Follow this and additional works at: https://repository.law.umich.edu/articles

Part of the Civil Procedure Commons, and the State and Local Government Law Commons

\section{Recommended Citation}

Sunderland, Edson R. "The Usefulness of Intervention as a Remedy in Attachment." Mich. L. Rev. 20 (1921): 96-8.

This Response or Comment is brought to you for free and open access by the Faculty Scholarship at University of Michigan Law School Scholarship Repository. It has been accepted for inclusion in Articles by an authorized administrator of University of Michigan Law School Scholarship Repository. For more information, please contact mlaw.repository@umich.edu. 
THE USEFULNESS OF INTERVENTION AS A REMEDY IN ATTACHMENT.While rules of procedure are not saved from the rude hand of the reformer by the "due process" guarantees of our constitutions, they do rest, nevertheless, under the very efficient protection of professional conservatism. Such rules are looked upon by the bench and bar as their own special concern, and innovations in this field must maintain the burden of proving their character before both the lawyer members of the legislature and the lawyers and judges who interpret them in the course of litigation. It would be natural, therefore, to expect that a proposed reform in procedure would have to meet at least the possibility of two shrinking processes, one at the hands of the legislature and the other at the hands of the court. An interesting case of the latter kind is found in Chase v. Washtenaw Circuit Judge, (Mich., I92I), I83 N. W. 63 .

In that case the petitioner, who claimed that her property had been wrongfully attached as the property of another sought to intervene in the attachment suit for the purpose of freeing it from the lien of the wrongful levy. The Michigan statute passed in I9I5 (C. L. 1915, Sec. 12362) allowed an intervention in any action by anyone claiming an interest in the litiga- 
tion. The court held that the "petitioner does not assert any interest in the litigation, and only seeks to free her property from a claimed wrongful attachment." Therefore, it was held that she could not intervene, but must let the attachment proceedings take their course against her property.

A contrary decision would have secured to the people of Michigan a much needed simplification of procedure and could have been justified on both reason and authority much more easily than the decision that was made. A study of contemporary American practice in such cases discloses the following interesting features.

In the first place, it appears that the widespread recognition of the great practical value of intervention in attachment cases has resulted in the enactment of a large number of statutes expressly providing for intervention by the owner of property claimed to have been wrongfully attached as the property of another. Even such conservative jurisdictions as Illinois (Juillard \& Co. v. May, (1889), I3o I1l. 87); Mississippi (Dreyfus v. Mayer, (I891), 69 Miss. 282) ; Florida G. S., 1906, Sec. 2129); Georgia (CodE, I9II, Secs. 5II5, 5116), and West Virginia (Capehart's Ex'r v. Dowery, (I877), ro W. Va. 130), which have refused to accept any thoroughgoing reform in pleading and still adhere to the common law system, have, nevertheless, enacted statutes expressly authorizing such intervention in attachment cases. Kansas (Bodwell v. Heaton, (I888), 40 Kan. 36) ; Arkansas (S. \& H. Sr., I894, Sec. 406), and Oklahoma (Miller v. Campbell Commission Co., (I903), I3 Okla. 75), states usually more friendly to such reforms, have similar statutes.

In the next place, it appears that the value of such a remedy has appealed so strongly to a number of courts that they have, in the absence of any statute at all on the subject, authorized the practice as an exercise of their inherent power to regulate their own procedure. This was the case in Sims v. Goettle, (1880), 82 N. C. 268 ; in United States v. Neely, (1906), 146 Fed. 764 , and in Daniels v. Soloman, (I897), in App. D. C. 163 , the latter asserting the existence of a similar judicial attitude in Maryland. In the Neely case, supra, the court saw no difficulty in the matter at all, and approved the intervention on the simple ground that "in that way a decision can be reached much more quickly and economically than in any other."

Lastly, it appears that a large number of states have general statutes of intervention substantially similar to the Michigan statute, and the decisions of courts acting under these statutes have been almost unanimous in favor of allowing such an intervention in attachment cases. Such was the decision in each of the following cases: Patton v. Madison Nat. Bank, (Ig07), 126 Ky. 469; City Nat. Bank. v. Crahan, (1907), I35 Iowa, 230; Hannon v. Connett, (1897), to Col. App. I7I; Dennis v. Kolm, (1900), I3I Cal. 91 ; Potlach Lumber Co. v. Runkle, (1909), I6 Ida. 192; Field v. Harrison, (I868), 20 La. Ann. $4 \mathrm{II}$; Lee v. Bradle, (I820), 8 Mart. (La.) 20; Houston Real Estate Inv. Co. v. Heckler, (IgI4), 44 Utah, 64. The last case above cited contains a very thorough study of the question, and demonstrates the simplicity, directness and speed with which the conflicting claims to 
attached property can be determined by this method. In two states alone, so far as we have discovered, Nebraska (Dunker v. Jacobs, (Ig07), 79 Neb. 435), and New Mexico (Meyer \& Sons Co. v. Black, (1888), 4 N. Mex. 352), has this use of the remedy of intervention under general intervention statutes like that in Michigan been disapproved.

E. R. S. 